\title{
Transoral Endoscopic Diverticulostomy of Zenker's Diverticulum With Energy Device
}

\author{
Hyunbum Kim (D), Yeonhee Im, Heesun Ahn, and Younghak Park (D) \\ Department of Otolaryngology-Head and Neck Surgery, College of Medicine, The Catholic University of Korea, Seoul, Korea
}

\section{Zenker 게실 환자에서 내시경적 접근법을 통해 Energy Device를 이용한 게실절개술 1예}

김현범 · 임연희 · 안희선 · 박영학

가톨릭대학교 의과대학 이비인후과학교실

Received June 2, 2021

Revised August 3, 2021

Accepted August 18, 2021

Address for correspondence

Younghak Park, MD, PhD

Department of Otolaryngology-

Head and Neck Surgery,

College of Medicine,

The Catholic University of Korea,

1063 -ro, Yeongdeungpo-gu,

Seoul 07345 , Korea

Tel $+82-2-3779-2219$

Fax $+82-2-780-9114$

E-mail yhpark7@catholic.ac.kr
Zenker's diverticulum (ZD) is an abnormally protruding space in the Killian triangle due to weakness between the inferior pharyngeal constrictor muscle and cricopharyngeal muscle. A rare disease that is found more often in the West than in the East, it occurs in the elderly, inducing dysphagia, globus symptom, reflux and etc. For the treatment, various transoral endoscopic techniques have been developed over the past 20 years: these include flexible and rigid endoscopy are used and several devices like scissors, staplers, $\mathrm{CO}_{2}$ laser and energy device. We report here the first case using the endoscopic energy device assisted diverticulostomy of ZD in Korea. Transoral endoscopic treatment is less invasive than classical transcervical approach treatment, showing better clinical course and results. Both rigid endoscope and energy device are also very familiar to head and neck surgeons, so this approach can be one of the best treatments for ZD. Korean J Otorhinolaryngol-Head Neck Surg 2022;65(4):226-30

Keywords Digestive system endoscopic surgery; Diverticulum; Endoscope; New device approval; Zenker.

\section{서 론}

Zenker 게실(Zenker's diverticulum, ZD)은 Killian triangle에 발생하는 게실로서 전세계적으로 유병률은 10000명당 $1-11$ 명으로 보고되는 드문 질환이다.,2) 노화와 강한 상관관 계를 보여 주로 60 대 이상의 고령층에서 발생하고 40대 이하 에서는 거의 발생하지 않는 특성이 있으며, 성별로는 남자에 서 2-3배 더 흔한 것으로 알려져 있고, 지역적으로는 동양보 다는 서양 특히 유럽에서 주로 발생하는 것으로 알려져 있다. 국내에서는 매우 드문 질환으로, 진단되는 경우도 많지 않으 며 치료 역시 경과 관찰 또는 경부접근법을 이용한 수술적 제 거인 경우가 많다. 하지만 유럽을 비롯하여 국내보다 더 높은

This is an Open Access article distributed under the terms of the Creative Commons Attribution Non-Commercial License (https://creativecommons.org/licenses/by-nc/4.0) which permits unrestricted non-commercial use, distribution, and reproduction in any medium, provided the original work is properly cited.
유병률을 보이는 곳에서는 내시경을 이용한 치료 방법이 다 양하게 보고되고 있다. ${ }^{3-5)}$ 경직형 내시경을 이용한 ZD의 수술 적 치료는 아직 국내에서 보고되지 않은 가운데, 특히 게실절 개술의 도구로 energy device를 이용한 방법 또한 그 사례가 국내에 아직 없는 바 문헌 고찰과 함께 보고하는 바이다.

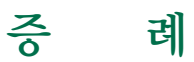

65세 남자 환자가 수개월 전부터 발생한 목이물감을 주소 로 내과에서 역류성 식도염 치료를 2달간 하였으나 호전이 없 으며, 내원 1달 전부터 목소리 변화도 동반되어 본원 외래 내 원하였다. 과거력상 고혈압 외 특이 소견 없었고, 40 갑년의 흡 연력은 있으나 3 년 전부터 금연 중이며, 음주력은 주 3 회 정도 였다. 외래에서 시행한 후두내시경상 좌측 $1 / 3$ 부근에 쌀알 크기의 고정된 백반증 양상의 종괴가 관찰되어 $\mathrm{CO}_{2}$ laser를 
이용한 후두미세수술을 시행하였으며, 병리 결과 squamous cell carcinoma in situ 나왔다(Fig. 1). 이후 주기적으로 외래 에서 추적 관찰하며 내시경상 재발이나 다른 특이 소견은 없 음을 확인하였으나, 지속적으로 목이물감을 호소하여 수술

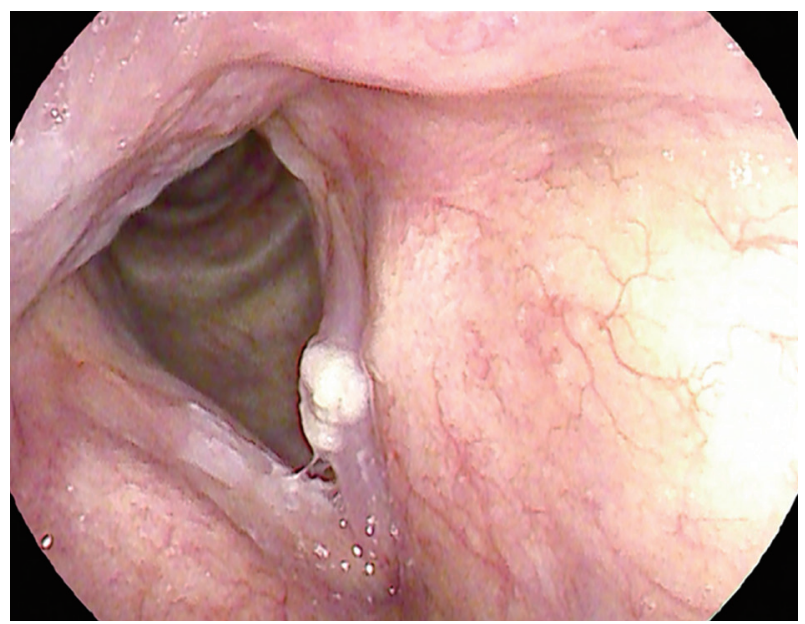

Fig. 1. Whitish fixed mass is shown in anterior $1 / 3$ portion of left vocal cord and reactive nodule is shown in right vocal cord. The pathologic result is squamous cell carcinoma in situ.
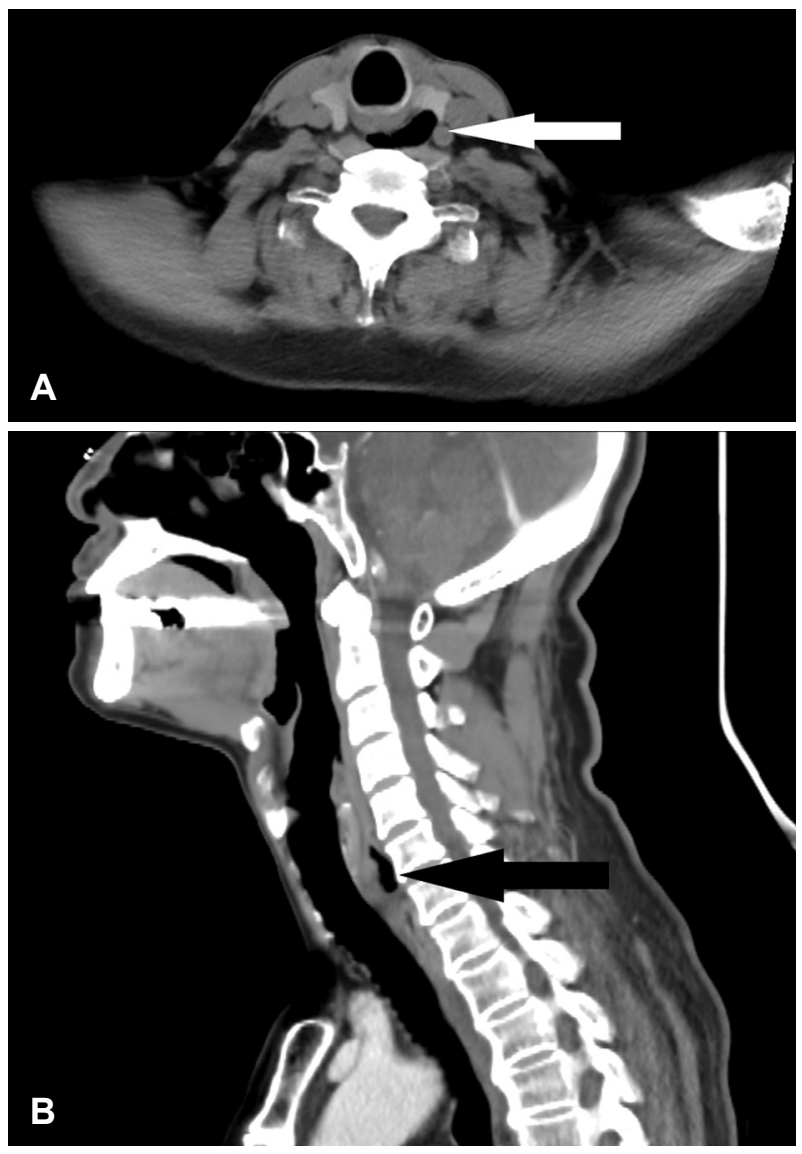

Fig. 2. Contrast enhance CT image shows Zenker's diverticulum. A: $3.0 \times 1.1 \mathrm{~cm}$ sized diverticulum (white arrow) is shown in axial image. B: $2.0 \mathrm{~cm}$ length diverticulum (black arrow) is shown in sagittal image.
후 1 년째 되는 시기에 경부 컴퓨터단층촬영을 시행하였다. 그 결과 전이나 재발 등의 소견은 없었으나 1 년 전보다 사이즈가 증가한 $\mathrm{ZD}$ 가 확인되어(Fig. 2) 수술을 계획하였으며, 접근 방 법으로 구강을 통한 내시경적 접근법을 선택하였다. 수술 전 환자는 비위관을 삽입하였고, 전신마취 후 반듯이 누운 자세 를 취하였다. 이후 경직형 후두내시경을 식도입구 부위에 넣 고 $\mathrm{ZD}$ 가 보이도록 위치를 고정하였다(Fig. 3). 경직형 후두내 시경을 통하여 0도 내시경과 복강경 때 주로 사용하는 $36 \mathrm{~cm}$ Harmonic Scalpel (Ethicon Endo-Surgery, Cincinnati, $\mathrm{OH}, \mathrm{USA}$ )을 삽입한 후 $\mathrm{ZD}$ 와 식도 사이의 중격을 제거하고 지혈을 한 뒤 수술을 마쳤다(Fig. 4). 수술 시간은 약 25분 정도 소요되었으며 다른 특이 사항이나 합병증 등은 없었다. 수술 후 2일 뒤 비위관 제거 및 경구 식이를 시작하려 하였 으나 수술 부위 통증이 남아있어 비위관을 유지하고 식사도 비위관으로 지속하였다. 수술 후 6일째 경부 컴퓨터단층촬영 을 시행하여 수술 부위 천공이나 다른 합병증 없음을 확인하 고, 통증 역시 호전을 보여 비위관을 제거하고 경구 식이를 시 작하였다. 수술 후 9일째 식도조영술을 시행하여 잘 회복되 었음을 확인하였고, 환자 역시 이물감이나 식이 장애, 통증 모두 호전을 보이며 퇴원하였다(Fig. 5).

\section{고 찰}

Zenker 게실(ZD)은 국내에서 흔치 않은 질환으로 주로 6070대 노년층에서 발병한다. 기존의 치료는 크기가 작거나 증 상이 경미할 경우에는 경과 관찰을 하지만 크기가 커서 구취, 역류 등의 연하장애 등 환자가 불편함을 느끼거나 감염이나 염증 등의 합병증 등이 있을 경우에는 수술로서 제거한다. 수

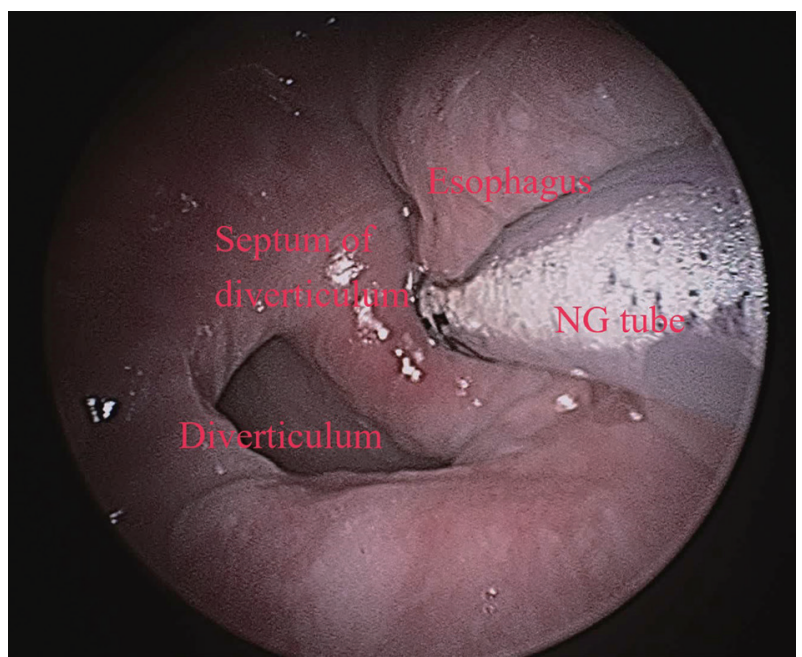

Fig. 3. Esophagus, NG tube, Zenker's diverticulum opening and septum is identified by 0 degree endoscopy via rigid laryngoscopy. NG, nasogastric. 

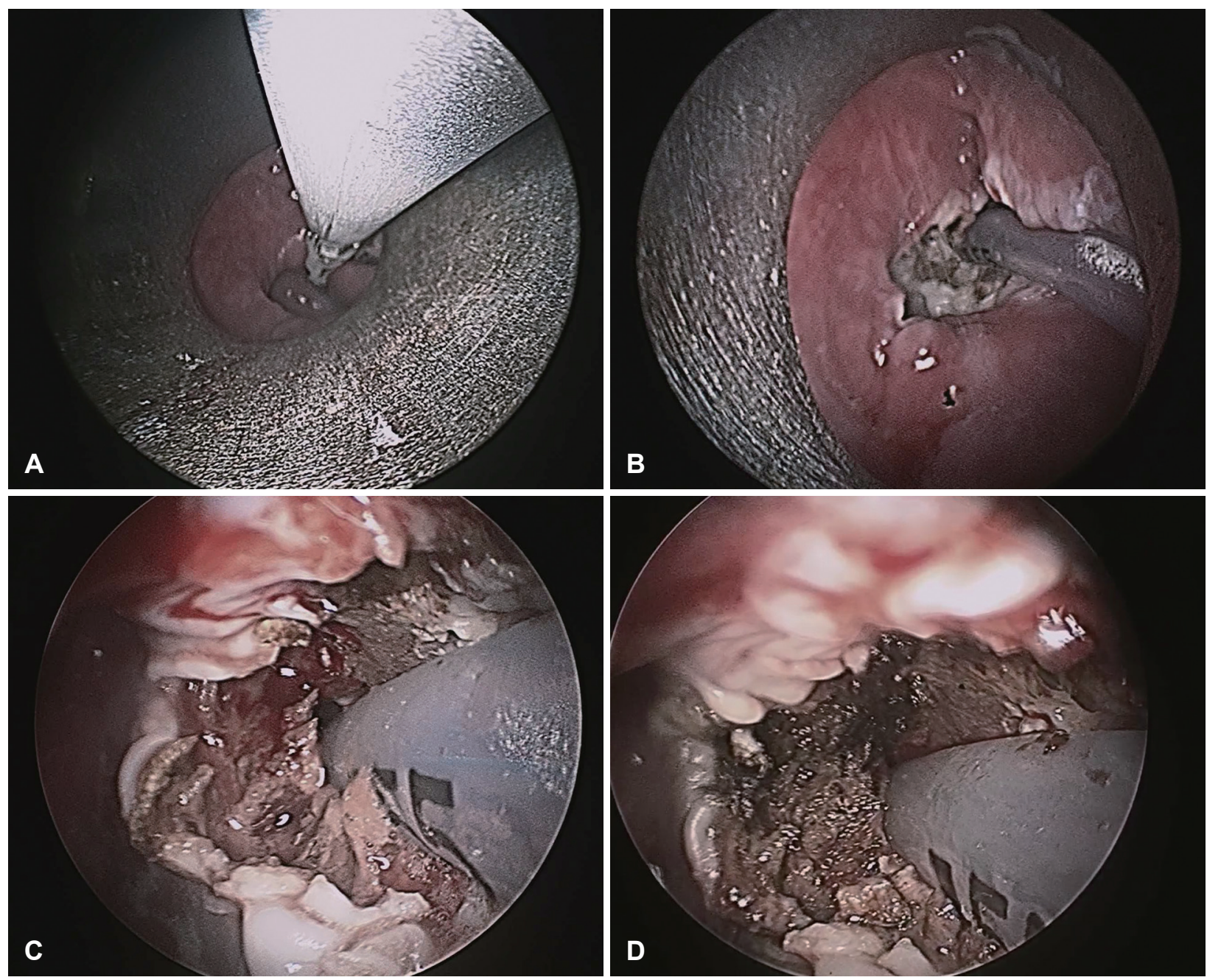

Fig. 4. Images of diverticulotomy. A: Harmonic scalpel is inserted. B and C: The mucosal surface is resected (B), and mucosa and posterior esophagus wall is resected to the height of bottom of diverticulum (C). D: Bleeding control is done and then procedure is finished.

술은 주로 경부접근법을 통한 윤상인두근절개술(cricopharyngotomy) 또는 게실절제술(diverticulectomy)을 시행하는 데, 국내보다 사례가 많은 외국에서는 경구접근법을 통하여 내시경적으로 치료하는 방법이 최근 많이 소개되고 있다.,2,6) 경구접근법은 경부접근법에 비해 수술 시간이 짧고 간단하 며 덜 침습적이라는 장점이 있으나, 목이 짧거나 경직되어 뒤 로 목을 젖히지 못하는 환자, 이전에 경부접근법으로 수술받 았던 환자, 게실이 상부식도 외 다른 곳에 위치한 환자에게는 경구접근법보다는 경부접근법을 선호한다. 또한 게실과 식도 사이의 막이 유착이나 섬유화가 없을 경우에는 경구접근법 으로 수술 후 천공이 보다 쉽게 발생할 수 있기에 이런 경우 에는 경부접근법을 선호한다. ${ }^{7)}$ 경구접근법은 크게 경직형 내 시경을 이용한 방법과 굴곡형 내시경을 이용한 방법으로 나 눌 수 있으며, 게실절개술의 재료로 scissores, laser, stapler, harmonic scalpel 등으로 구분할 수 있다. ${ }^{3-5,89)}$ 모든 시술이
장·단점이 있는 가운데, 공통적으로 식도와 $\mathrm{ZD}$ 의 사이의 중 격을 많이 제거하면 재발하지 않고 치료 효과가 좋은 대신 천 공의 위험성이 올라가는 반면, 중격을 조금 제거하면 재발의 가능성이 있었다. ${ }^{6}$ 천공과 출혈을 예방하고자 stapler를 사 용한 방법들도 있었지만 그렇지 않은 방법들과 천공예방의 유의미한 차이는 없는 것으로 보였다.

마취 방법은 midazolam을 이용한 진정요법과 전신마취 모두 가능하며 결과에 큰 차이는 없었다. 다만 진정요법을 사 용한 경우 대부분 좌측으로 모로 누운 자세(lateral decubitus position)를 취하였으며, 전신마취인 경우에는 양와위(supine postion) 및 모로 누운 자세의 큰 차이는 없었다. 비위관 삽입 및 게실경(diverticuloscope)의 사용은 보조적으로 사용될 수 있었으나 반드시 필요한 도구는 아니며, 출혈 및 천공의 위험 성을 낮춘다는 보고들도 있으나 이는 더 많은 연구가 필요한 것으로 보인다. ${ }^{4,699}$ 본 사례의 경우 후두미세수술과 비슷하게 


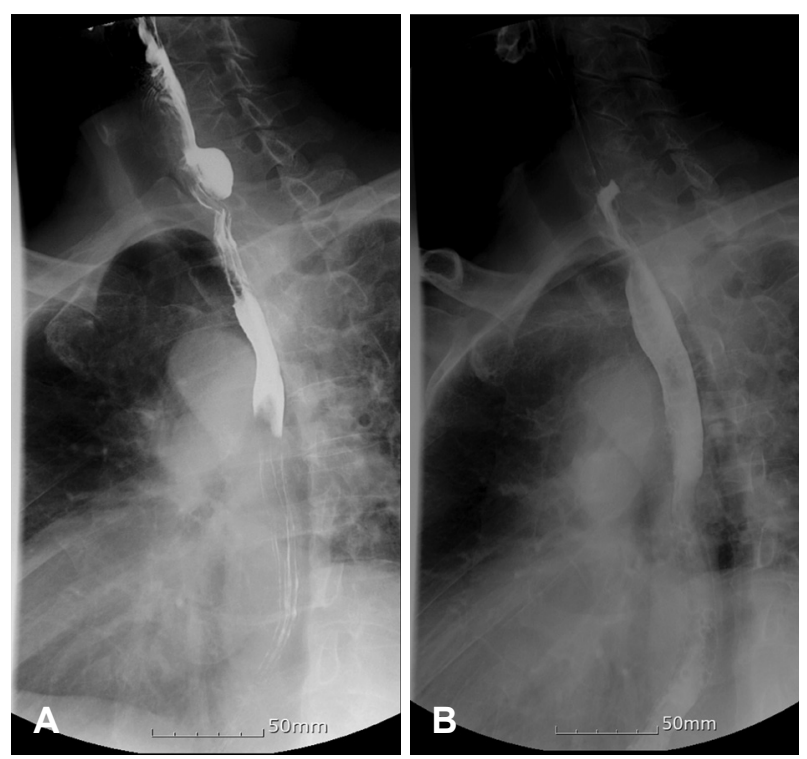

Fig. 5. Preop and postop esophagography images shows improvement of ZD. A: Preop image shows oval-shaped ZD and confirmed that the contrast is accumulating there. B: Postop image shows the loss of septum between esophagus and diverticulum, so one single cavity is observed. ZD, Zenker's diverticulum.

전신마취하 양와위 자세로 시행하였고, 강직형 내시경을 이용 하여 진행하였기에 게실경은 필요치 않았으며, 본 사례가 첫 시도인만큼 더 나은 해부학적 위치관계 파악을 위해 비위관 은 삽입하였다.

수술 중 주된 합병증은 출혈이다.,2,6) 수술 중 출혈은 대부 분 쉽게 지혈이 되는 것으로 보고된다. 수술 시간은 10-70분 정도로 다양하게 보고되고 있는데, ${ }^{1,2}$ 게실의 크기와 수술자 의 숙련도 등이 영향을 끼치는 것으로 보인다. 본 사례에서는 수술 중 출혈은 거의 없었으며, 수술이 끝났을 때 관찰되는 경미한 출혈 역시 쉽게 지혈이 되었다. 내시경 삽입부터 제거 까지 총 시술 시간은 약 25 분 정도 소요되었다. 내시경 삽입 은 후두미세수술과 비슷한 방법으로 하되, 게실이 잘 보일 수 있는 곳에 위치시켰다.

수술 후 합병증으로 출혈과 천공이 발생할 수 있는데, $1,2,6$ 천공의 가능성은 강직형 내시경을 사용하였을 경우 평균 $2 \%$ (0\%-8\%) 정도로 보고되며, 굴곡형 내시경은 평균 $4 \%$ (0\%$16 \%)$ 정도로 보고되나 통계적으로 유의하지는 않다. ${ }^{1-3,6,9,10)}$ 사망의 이르는 경우는 매우 드물었으며, 천공으로 인한 종격 동염 또는 종격동 고름집이 생기는 경우도 $1 \%-4 \%$ 정도 있는 것으로 알려져 있으며 $1 \%$ 이하의 경우로 배액이나 추가적인 수술 등이 필요한 것으로 보고된다. 천공을 예방하는 방법은 여러 가지가 있다. 식도와 게실 사이의 중격을 모두 제거할 경 우에는 식도의 세로근육을 보존하는 것이 중요하지만 식도와 게실 사이의 중격에 교통할 수 있는 통로나 다리만 놓는 개념 의 게실중격절개술일 경우 식도 세로근육 역시 일부 제거할
수 있는 것으로 보고되고 있다. ${ }^{1.2)}$ 하지만 여러 논문에서 공통 적으로 게실의 하부벽 높이 이하로 중격을 제거하면서 식도 근육의 바깥층을 잘 보존할 경우 천공은 거의 발생하지 않는 것으로 알려져 있다. ${ }^{2,58)}$ 또한 게실과 식도의 후두벽 사이에 유착이나 섬유화가 진행되어 있을 경우에도 천공이 덜 발생 하는 것으로 보고되고 있다. ${ }^{2)}$ 본 사례에서는 게실과 식도 사 이에 교통할 수 있는 통로를 만드면서 깊이는 게실의 하부벽 과 비슷하거나 그보다 얕게 제거하였다. 또한 게실과 식도벽 사이의 바깥 점막을 최대한 잘 보존하면서 시술을 하여 천공 을 예방하였다. 이 외 수술 후 통증, 일시적인 연하장애 등 경 미한 합병증 등도 $6 \%$ (0\%-38\%) 정도 보고되지만 보존적인 치료로 충분한 것으로 알려져 있다. ${ }^{2,6)}$ 수술 후 경구 식이는 각각의 연구마다 다르지만 1-5일 정도 지난 뒤 경구 식이를 시작하였다. 본 사례에서는 수술 후 통증과 같은 경미한 증상 은 있었고 이로 인해 경구 식이는 수술 후 6일째 경구 식이를 하였으며, 천공이나 종격동염 등의 중증의 합병증은 없었다.

재발율은 약 $10 \%$ 정도로 보고되고, ${ }^{1,2}$ 그 중 대다수는 다 시 내시경을 이용한 경구 접근 방법으로 완치되는 것으로 알 려져 있으나 $1 \%$ 정도에서는 경부접근법으로 수술이 필요한 것으로 알려져 있다.)

여러 연구를 종합해보면 기존의 시행되어 왔던 경부접근법 을 이용한 윤상인두근절개술 또는 게실절제술보다 경구접근 법을 이용한 내시경적 게실절개술이 수술 방법이 간단하고 수술 시간 및 입원기간이 짧으며 부작용은 덜 하지만 치료 성 공률은 비슷하거나 높은 것으로 보고되고 있다. $2,3,5,6,8,9)$ 내시 경 선택에서 강직형과 굴곡형 두 가지 모두 가능하지만, 경비 식도내시경(transnasal esophagoscopy) 외 수술방에서 굴곡 형 내시경을 사용하지 않는 이비인후과 의사 입장에서는 미 세후두수술 등과 같이 수술방에서 자주 사용하는 강직형 내 시경을 이용한다면 어렵지 않게 내시경을 이용한 게실절개술 을 시행할 수 있을 것이라 생각된다. 또한 게실절개 때 사용 하는 도구로서 $\mathrm{CO}_{2}$ laser나, Bovie electrocauterization 등도 가능하다고 되어 있으나 본 사례처럼 수술 시 자주 사용하는 harmonic scalpel을 이용하면 보다 쉽게 익숙해질 수 있을 것이라 생각된다. ${ }^{8}$ 하지만 강직형 내시경을 사용할 경우 미 세후두수술과 마찬가지로 목이 짧은 환자나 혀가 굵은 환자, 비만 등이 있는 환자는 내시경 삽입이 어려울 수 있으며, 게 실이 너무 작을 경우 식도 뒷벽이 시술 중 쉽게 손상받아 천 공의 위험성이 증가하고, 게실에 염증이 동반되어 있는 경우 또는 주요 혈관등이 근접한 경우에는 경부접근법이 필요할 수 있으니 수술 전 이에 대한 확인이 필요할 것으로 보인다.2) 


\section{Acknowledgments \\ None}

\section{Author Contribution}

Conceptualization: all authors. Data curation: Hyunbum Kim, Yeonhee Im, Heesun Ahn. Formal analysis: Younghak Park. Investigation: all authors. Methodology: Younghak Park. Project administration: Hyunbum Kim. Resources: al authors. Supervision: Younghak Park. Visualization: Yeonhee Im, Heesun Ahn. Writingoriginal draft: Hyunbum Kim. Writing — review \& editing: Hyunbum Kim, Younghak Park.

\section{ORCIDs}

Younghak Park https://orcid.org/0000-0001-7334-0303

Hyunbum Kim

$$
\text { https://orcid.org/0000-0003-1802-8952 }
$$

\section{REFERENCES}

1) Ferreira LE, Simmons DT, Baron TH. Zenker's diverticula: Pathophysiology, clinical presentation, and flexible endoscopic management. Dis Esophagus 2008;21(1):1-8.

2) Law R, Katzka DA, Baron TH. Zenker's diverticulum. Clin Gastroenterol Hepatol 2014;12(11):1773-82.

3) Goelder SK, Brueckner J, Messmann H. Endoscopic treatment of
Zenker's diverticulum with the stag beetle knife (sb knife) feasibility and follow-up. Scand J Gastroenterol 2016;51(10):1155-8.

4) Gutierrez OIB, Ichkhanian Y, Spadaccini M, Vosoughi K, Repici A, Khashab MA. Zenker's diverticulum per-oral endoscopic myotomy techniques: Changing paradigms. Gastrointest Endosc 2019;89(6 Suppl):AB134.

5) Repici A, Spadaccini M, Belletrutti PJ, Galtieri PA, Fugazza A, Anderloni A, et al. Peroral endoscopic septotomy for short-septum Zenker's diverticulum. Endoscopy 2020;52(7):563-8.

6) Jain D, Sharma A, Shah M, Patel U, Thosani N, Singhal S. Efficacy and safety of flexible endoscopic management of Zenker's diverticulum. J Clin Gastroenterol 2018;52(5):369-85.

7) Law R, Katzka DA, Baron TH. Zenker's diverticulum. Clin Gastroenterol Hepatol 2014;12(11):1773-82; quiz e111-2.

8) Hondo FY, Maluf-Filho F, Giordano-Nappi JH, Neves CZ, Cecconello I, Sakai P. Endoscopic treatment of Zenker's diyerticulum by harmonic scalpel. Gastrointest Endosc 2011;74(3):666-71.

9) Ramchandani M, Nageshwar Reddy D. New endoscopic "scissors" to treat Zenker's diverticulum (with video). Gastrointest Endosc 2013;78(4):645-8.

10) Klingler MJ, Landreneau JP, Strong AT, Barajas-Gamboa JS, Tat C, $\mathrm{Tu} \mathrm{C}$, et al. Endoscopic mucosal incision and muscle interruption (MIMI) for the treatment of Zenker's diverticulum. Surg Endosc 2021;35(7):3896-904. 